11 Caner, J. E. Z., and Decker, J. L., American fournal of Medicine, 1964, 36, 571.

12 Davidson, R. C., and Pendras, J. P., Transactions of the American Society for Artificial Internal Organs, 1967, 13, 36.

13 Hegstrom, R. M., Murray, J. S., Pendras, J. P., Burnell, J. M., and Scribner, B. H., Transactions of the American Society for Artificial Internal ner, B. H., Transactions
Organs, $1962,8,266$.

14 Cogan, D. G., Albright, F., and Bartter, F. C., Archives of Ophthalmology, $1948,40,624$.

15 Wing, A. J., American Heart fournal, 1969, 78, 836.

16 Goldsmith, R. S., Furszyfer, J., Johnson, W. J., Fournier, A. E., and Arnaud, C. D., American fournal of Medicine, 1971, 50, 692.

17 Boner, G., Jacob, E. T., Pevzner, S., and Jungmann, A., Israel fournal of Medical Sciences, 1971, 7, 1182.

18 Walser, M., Fournal of Clinical Investigation, 1962, 41, 1454

19 Yendt, E. R., Connor, T. B., and Howard, J. E., Bulletin of the Fohns Hopkins Hospital, 1955, 96, 1.

20 Russell, R. G. G., Bisaz, S., and Fleisch, H., Archives of Internal Medicine, $1969,124,571$

21 Bishop, M. C., Ledingham. J. G. G., and Oliver, D. O., in Proceedings of the European Dialysis and Transplant Association, ed. J. S. Cameron, C. S. Ogg, and D. Fries, 1971, 8, 106. London, Pitman.

22 Garner, A., and Ball, J., fournal of Pathology and Bacteriology, 1966, 91,

${ }^{23}$ Kerr, D. N. S., in Proceedings of the European Dialysis and Transplant Association, ed. J. S. Cameron, C. S. Ogg, and D. Fries, 1971, 8, 160. London, Pitman.

24 Russell, R. G. G., Smith, R., Bishop, M. C., Price, D. A., and Squire, C. M., Lancet, 1972, 1, 10 .

25 Cram, R. L., Barmada, R., Geho, W. B., and Ray, R. D., New England fournal of Medicine, 1971, 285, 1012.

\section{Bladder Cancer and Smoking}

Sixteen years ago A. M. Lilienfeld and colleagues ${ }^{1}$ showed by a case-control (retrospective) epidemiological investigation an association between cigarette smoking and bladder cancer. Their observation has since been confirmed by similar studies, ${ }^{2-5}$ and there can be no doubt about its validity. Nevertheless, doubts have been expressed about its interpretation in terms of causality on the grounds that the association is weak (the relative risk of smokers compared with non-smokers is just about double), that it seems to be absent in women, and that the mechanism is obscure.

Though weak, the association is consistent and is stronger among heavy than among light smokers. The most recent case-control study, from the Harvard School of Public Health, ${ }^{6}$ shows that the association also exists for women and that the relation is of about the same magnitude as for men. Men cigarette smokers had a relative risk of bladder cancer of 1.89 compared with non-smokers, and about $39 \%$ of the cases were related to smoking ("attributable risk"). Among women cigarette smokers the comparable relative risk was 2.00 and the comparable attributable risk $29 \%$. None of the greater risk associated with smoking could be explained by an indirect association with type of occupation. The report also pointed out that in successive cohorts increasing rates of incidence of bladder cancer in American women are matched by an increase in cigarette smoking.

R. Hoover and P. Cole, ${ }^{7}$ also from the Harvard School of Public Health, have now examined in some detail trends in smoking habits and bladder cancer for successive cohorts of men and women in the United States, Denmark, and England and Wales. Their findings greatly strengthen the case for the prosecution. They show that the cohort patterns of rising rates of incidence of bladder cancer observed are in line with the corresponding patterns of rising cigarette consumption. The association is consistent for both sexes, for the three nationalities, and for urban and rural groups. In the authors' own words, "this makes it unlikely that the findings result from an association of both smokers and bladder cancer with a third variable." They also point out that cohort-specific rates of incidence of bladder cancer are now levelling off or even beginning to decline, and they tentatively suggest that this may be due to a concurrent levelling off of the percent of cigarette smokers and the decline of the percent of heavy smokers in recent cohorts. Another piece of the jigsaw that fits into place is the demonstration by A. J. Lea $^{8}$ of a highly significant correlation between death rates from lung cancer and cancer of the bladder for 20 countries. The only obvious aetiological factor common to both these cancers is cigarette smoking.

How smoking gives rise to this type of cancer remains obscure. As long ago as 1955 L. R. Holsti and P. Ermala9 claimed to have produced papilloma of the bladder in mice by painting the buccal mucosa with tobacco-smoke condensates. Their findings have not been confirmed. Certain normal metabolites of tryptophan have been shown to induce cancer of the bladder in mice. ${ }^{10} 11$ In one small study ${ }^{12}$ these metabolites were found in greater amounts in the urine of cigarette smokers than of non-smokers, and the amounts decreased when the smokers stopped smoking and increased when the non-smokers began to smoke. And there the matter at present rests.

Cigarette smoking is one of the most lethal of the common environmental hazards. To the high risk it carries of cancer of the lung, coronary disease, and chronic bronchitis must now almost certainly be added a lower risk of cancer of the bladder.

${ }^{1}$ Lilienfeld, A. M., Levin, M. L., and Moore, G. E., Archives of Internal Medicine, 1956, 98, 129.

2 Schwarz, D., Flamant, R., Lellouch, J., and Denoix, P. J., Fournal of the National Cancer Institute, 1961, 26, 1085.

s Lockwood, K., Acta Pathologica Microbiologica Scandinavia, 1961, 51, suppl. No. 145.

Wynder, E. L., Onderdonk, J., and Mantel, N., Cancer, 1963, 16, 1388.

5 Deeley, T. J., and Cohen, S. L., in Proceedings of 5 th Inter-American Conference on Toxicology and Occupational Medicine. Aesculapius Conference on Toxicology and Occupational
Publishing Co., Birmingham, Alabama, 1966.

- Cole, P., Monson, R. R., Haning, H., and Friedell, G. H., New Zealand Fournal of Medicine, 1971, 284, 129.

7 Hoover, R., and Cole, P., American fournal of Epidemiology, 1971, 94, 409. 8 Lea, A. J., Lancet, 1966, 1, 590.

2 Holsti, I.. R., and Ermala, P., Cancer, 1955, 8, 679.

Allen, M. J., Boyland, E., Dukes, C. E., Horning, E. S., and Watson, J. G., British fournal of Cancer, 1957, 11, 212. 11 Bryan, G. T., Brown, R. R., and Price, J. M., Cancer Research, 1964, 24,

12 Kerr, W. K., Barkin, M., Levers, P. E., Woo, S. K. C., and Menczyk, Z., Canadian Medical Association fournal, 1965, 93, 1.

\section{A New Faculty}

At an inaugural meeting held last week a Faculty of Community Medicine came into being. It is a joint faculty of the Royal College of Physicians of London, Edinburgh, and Glasgow (who include the surgeons with their physicians). Advocated by the Royal Commission on Medical Education $^{1}$ and heralded by the presidents of the three royal colleges, ${ }^{2}$ the new Faculty has surely been born with a silver spoon in its mouth. But the shape it takes in the coming years will depend more than usually on how its founding members set their course. The Faculty's first president is Professor A. L. Cochrane. A list of the other members of the Faculty board is given in our news pages at p. 812 .

Community medicine is not yet so clearly defined a branch of medicine as, say, pathology or psychiatry. A consultant cardiologist recently looking at the concept found himself peering "into an uncertain future," 3 and the chairman of 